\title{
Unexpected Feature of the Lepidoptera Assemblages on the Small Shelf Islands in the Peter the Great Gulf (Sea of Japan, South of Russian Far East)
}

\section{Evgeny A Beljaev*}

Institute of Biology and Soil Science, Vladivostok, Russia

*Corresponding author: Evgeny A. Beljaev, Institute of Biology and Soil Science, Far Eastern Branch of Russian Academy of Sciences, Vladivostok, 690022, Russia, Tel: +74232311133; Fax:+7423310193; E-mail: beljaev@ibss.dvo.ru

Received date: Apr 02, 2014, Accepted date: May 26, 2014, Publication date: May 29, 2014

Copyright: () 2014 Beljaev EA. This is an open-access article distributed under the terms of the Creative Commons Attribution License, which permits unrestricted use, distribution, and reproduction in any medium, provided the original author and source are credited.

\begin{abstract}
The article describes and discusses unexpected feature of agrological structure of the moths' species assemblages on four small shelf islands in the Peter the Great Gulf (Sea of Japan, south of Russian Far East). Before insect fauna of these islands was almost unknown. The study was conducted according to standard entomological procedures of insect collecting and chorological analysis of local faunas. Statistical analysis was performed using the detrended correspondence analysis. Typification of areas was made following the principles by Gorodkov. As a result, it was found that geometrid fauna demonstrates high degree of patchiness between the islands and species richness at times lesser than in neighboring continental localities. Nevertheless, a high similarity of agrological structure of the moths inhabited the islands and the continental localities was explored. This is unexpected because of low species richness of geometrids on the islands and their mosaic distribution between them, being original current climatic conditions on the islands and their separation from mainland at beginning of Holocene in different climatic epoch. Starting from the theory of island biogeography, and taking into account geography of the gulf, this fact could be explained by assuming that the moths on the islands represented mainly by resident populations, which occasionally, but regularly over long time intervals, are replenished by random immigrants from mainland. This random immigration could alignment of areological structure of moths between islands and mainland. This model could explain both a high degree of patchiness of the species composition of the moths on the islands, as well as a high degree of compliance of their arealogical structure to neighboring continental localities. However, this hypothesis assumes an equivalence of distribution of migratory ability of moths in large arealogical groups, which requires special research.
\end{abstract}

Keywords: Insecta; Lepidoptera; Geometridae; Arealogocal structure; Small islands; The peter the Great Gulf; Sea of Japan

\section{Introduction}

Islands, being separated from other land areas by water expanses, are clearly defined local terrestrial ecosystems with obstructed biotic external exchange. The degree of originality of insular biota depends on many factors. The leading are the area of island, its geological and climatic history and distance from nearest sources of recruitment of species. Generally, the larger island and the more it removed from the mainland and the longer tectonically and climatically "calmer" its geological history - the higher the expected originality of its biota. A great scientific interest to insular biota induced by expectation of new faunal discoveries also as by opportunity to study the structure of animal and plant communities and ways of their adaptation to the environment in almost pure conditions of a natural experiment.

Islands of the Peter the Great Gulf do not meet the conditions of expectation of a high degree originality of their biota. Most of them are relatively small or very small, located on the continental shelf near the coast and represent the top of underwater mountains on branches of coastal ridges. In the Pleistocene they were united with land and age of their separating is estimated in the range of 11 to 8.5 thousand years ago $[1,2]$ or less, depending on the height of the isthmus connecting the island with mainland. Therefore, the islands of the Peter the Great
Gulf cannot possess a high autochthonous endemism of animals or plants.

Nevertheless, several factors distinguish the islands from adjacent coast, as follow: more soft winter terms, as much as the gulf region free of solid ice; intensive marine fog at summer, providing high air humidity and temperature lower than on the continental coast; some soil moisture deficit because of good drainage and abundance of rocky substrates quickly-losing atmospheric condensation; and some degree of soil salinity, as in a storm sea spray entirely penetrates small and even medium-sized island. More details on climate and vegetation of the islands are in [3].

In general, environment of the islands is favourable for insect species requiring long period of development during the warm season, sensitive to low winter temperatures, but not demanding high summer ones, and resistant to strong wind, to high air humidity, to variable soil humidity and some soil salinity. These physical environment factors allow to expect a certain degree of originality of biota on the islands of the Peter the Great Gulf in comparison with the neighbouring continental localities.

Insect fauna of the islands is still largely unknown. On the moths and butterflies (order Lepidoptera) this information is limited to a few publications. There are a series of taxonomic works published at the end of the $19^{\text {th }}$ century [4-13], which describes materials collected by Jankowski and brothers F. and H. Dörries in 1877-1879 on the Askold Island [14]. Besides, a small list of butterflies and moths collected by 
Citation: Beljaev EA (2014) Unexpected Feature of the Lepidoptera Assemblages on the Small Shelf Islands in the Peter the Great Gulf (Sea of Japan, South of Russian Far East). J Biodivers Biopros Dev 1: 113. doi:10.4172/2376-0214.1000113

Page 2 of 5

Emelyanov and Rostovykh on the Furugelm Island in 1929 [15], and an overview of butterflies of islands in the Peter the Great Gulf [16] are available only.

Thus, weak research of Lepidoptera on islands of the gulf, in conjunction with a potential faunal and biogeographic interest of their fauna, caused the current study. The loopers (Insecta: Lepidoptera: Geometridae) were chosen as a model group for the study, because they are considered as an ideal group of moths for biogeographic studies due to its high taxonomic diversity, wide ecological diversification, comparative habitat conservatism and moderate migratory activity, combined with good detectability in nature [17] Detailed biogeographical analysis of the geometrid fauna on the islands of Peter the Great Gulf had been published previously [3]. Here I would like accentuate only one aspect of arealogical analysis.

\section{Materials and Methods}

Materials were obtained during the author's field studies in 1997 and in 2012 on the Rikord Island (area 5.0 sq. km.), on the Bolshoi Pelis Island (area $3.1 \mathrm{sq} . \mathrm{km}$.) and on the Furugelm Island (area 1.9 sq. $\mathrm{km}$.) (Figure 1). Moths collecting was made according to standard methods: at day time - with the air butterfly net and at night - on light (on white screen lighted with mercury-quartz lamp OSRAM HWL 500 W, fed by portable electric generator Honda EU 10i/G, and in two automatic light traps with compact fluorescent cold light lamp T5 Foton $6 \mathrm{~W} 6400 \mathrm{~K}$, powered by the rechargeable battery with a capacity of 10 ampere-hours).

The collecting covered the main biocenotic diversity of the islands ecosystems: forests of different types, open grass-shrub associations on the windward slopes and grass-covered coastal sand drifts. List of Geometridae for the Askold Island (area 14.6 sq. km.), was compiled from the literature $[4-6,8,9,13]$ with adaptation to current nomenclature and to modern understanding of species volume. List of species of the Furugelm Island was supplied from [15].

As a result, 209 species of Geometridae were identified on the islands, distributed as follows: the Askold Island - 142 species, the Ricord Island - 79 species, the Bolshoi Pelis Island - 55 species and the Furugelm Island - 107 species (see [3], Table 1).

For comparison with the islands, three local geometrid faunas from neighboring continental territories were taken: "Lazovsky Nature Reserve" (308 species), "Litovka mountain" (308 species) and "Razdolnaya river" (314 species) (Figure 1). They have been studied before $[18,19]$ (also see [3]). Set of the lists of species from the islands and from the local continental faunas were added with the list of geometrid of "Primorskii region" (=Primorsky Krai, Primorye, Maritime Province or Maritime Territory, Russia), which includes all localities treated here (533 species; extracted from [20]).

\begin{tabular}{|l|l|l|l|l|l|l|l|l|}
\hline $\begin{array}{l}\text { Arealogical } \\
\text { group }\end{array}$ & Ask. & Rick. & B.P. & Fur. & Laz. & Lit. & Razd. & Prim. \\
\hline Widespread & $\begin{array}{l}49 / \\
34,5 \\
\%\end{array}$ & $\begin{array}{l}26 / \\
32,9 \%\end{array}$ & $\begin{array}{l}18 / \\
32,7 \\
\%\end{array}$ & $\begin{array}{l}31 / \\
28,9 \\
\%\end{array}$ & $\begin{array}{l}33,8 \\
\%\end{array}$ & $\begin{array}{l}29,9 \\
\%\end{array}$ & $\begin{array}{l}30,6 \\
\%\end{array}$ & $\begin{array}{l}28,9 \\
\%\end{array}$ \\
\hline $\begin{array}{l}\text { Central } \\
\text { Palaearctic } \\
-\quad \begin{array}{l}\text { Eastern Far } \\
\text { Ear }\end{array}\end{array}$ & $\begin{array}{l}10,6 \\
\%\end{array}$ & $\begin{array}{l}5,1 \% \\
14,6\end{array}$ & $\begin{array}{l}8 / \\
\%\end{array}$ & $\begin{array}{l}9,5 \% \\
9,7 \%\end{array}$ & $\begin{array}{l}30 / \\
9,8 \%\end{array}$ & $\begin{array}{l}21 / \\
13,6 \\
\%\end{array}$ & $\begin{array}{l}65 / \\
12,3 \\
\%\end{array}$ \\
\hline
\end{tabular}

\begin{tabular}{|c|c|c|c|c|c|c|c|c|}
\hline East Asian & $\begin{array}{l}76 / \\
53,5 \\
\%\end{array}$ & $\begin{array}{l}44 / \\
55,7 \%\end{array}$ & $\begin{array}{l}29 / \\
52,7 \\
\%\end{array}$ & $\begin{array}{l}65 / \\
60,7 \\
\%\end{array}$ & $\begin{array}{l}166 / \\
53,9 \\
\%\end{array}$ & $\begin{array}{l}190 / \\
61,7 \\
\%\end{array}$ & $\begin{array}{l}169 / \\
53,8 \\
\%\end{array}$ & $\begin{array}{l}302 / \\
56,6 \\
\%\end{array}$ \\
\hline Far Eastern & $\begin{array}{l}2 / \\
1,4 \%\end{array}$ & $\begin{array}{l}2 / \\
2,5 \%\end{array}$ & $\begin{array}{l}0 / \\
0 \%\end{array}$ & $\begin{array}{l}0 / \\
0 \%\end{array}$ & $\begin{array}{l}5 / \\
1,6 \%\end{array}$ & $\begin{array}{l}1 / \\
0,3 \%\end{array}$ & $\begin{array}{l}3 / \\
1,0 \%\end{array}$ & $\begin{array}{l}5 / \\
0,9 \%\end{array}$ \\
\hline $\begin{array}{l}\text { East Asian - } \\
\text { Indo- } \\
\text { Malayan }\end{array}$ & $\begin{array}{l}0 / \\
0 \%\end{array}$ & $\begin{array}{l}3 / \\
3,8 \%\end{array}$ & $\begin{array}{l}0 / \\
0 \%\end{array}$ & $\begin{array}{l}1 / \\
0,9 \%\end{array}$ & $\begin{array}{l}3 / \\
1,0 \%\end{array}$ & $\begin{array}{l}4 / \\
1,3 \%\end{array}$ & $\begin{array}{l}3 / \\
1,0 \%\end{array}$ & $\begin{array}{l}7 / \\
1,3 \%\end{array}$ \\
\hline Total & $\begin{array}{l}142 / \\
100 \%\end{array}$ & $\begin{array}{l}79 / \\
100 \%\end{array}$ & $\begin{array}{l}55 / \\
100 \%\end{array}$ & $\begin{array}{l}107 / \\
100 \%\end{array}$ & $\begin{array}{l}308 / \\
100 \%\end{array}$ & $\begin{array}{l}308 / \\
100 \%\end{array}$ & $\begin{array}{l}314 / \\
100 \%\end{array}$ & $\begin{array}{l}533 / \\
100 \%\end{array}$ \\
\hline
\end{tabular}

Table 1: Number and proportion (\%) of geometrid species from different arealogical groups in local faunas in Primorskii region. Notations see Figure 2 and 3.

All the lists were converted into a table of Excel; the file served as a primary data matrix for further calculations. Detrended correspondence analysis [21] was made with using the software package PAST [22]. Classification of areas is given in accordance with the principles by Gorodkov [23,24] adapted to the Far East region and the family Geometridae by Beljaev [25].

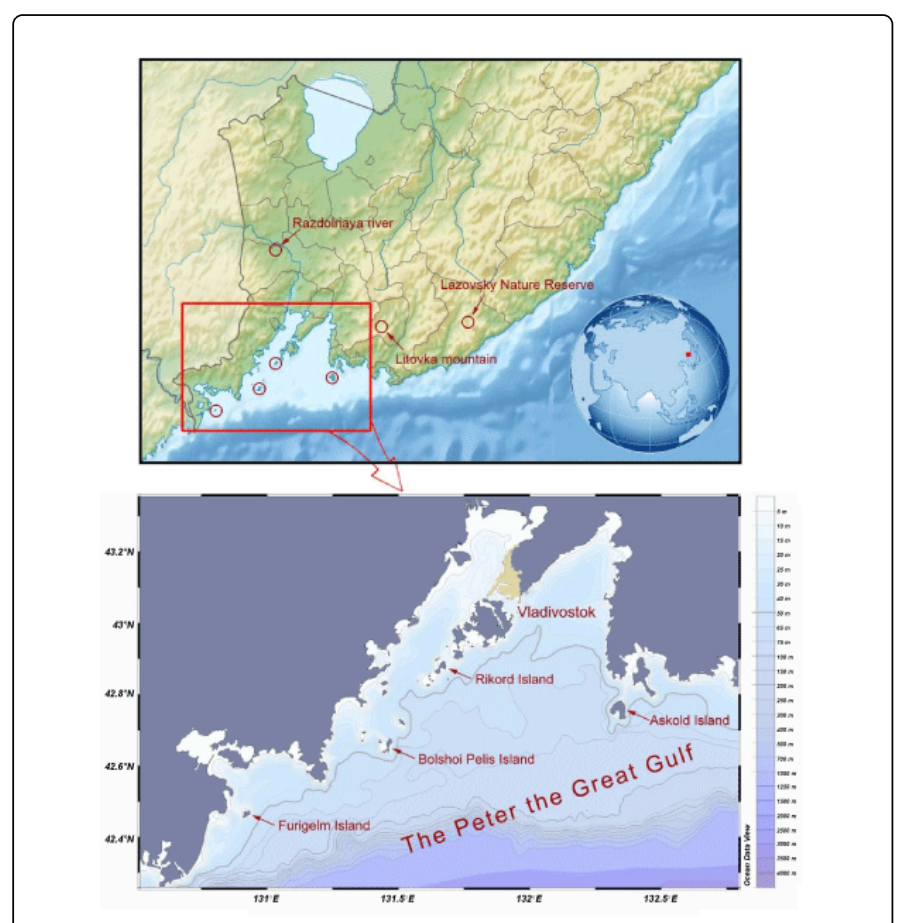

Figure 1: Location of the collecting sites.

\section{Results}

Quantitative analysis of the species composition differences between the analyzed local faunas shows low similarity of the insular geometrid faunas to each other. Average degree of this similarity is significantly lower of the similarity between the continental local faunas, despite the high biocenotic affinity of the islands (Figure 2). Thus, we can speak about a high degree of patchiness of geometrid distribution on the islands. Indeed, only 10 species were recorded on 
all four islands or barely $4.8 \%$ of all 208 ones, totally found on the islands. Tree islands possess by significantly more common species 43 , however, this amount is only $20.7 \%$ of all 208.
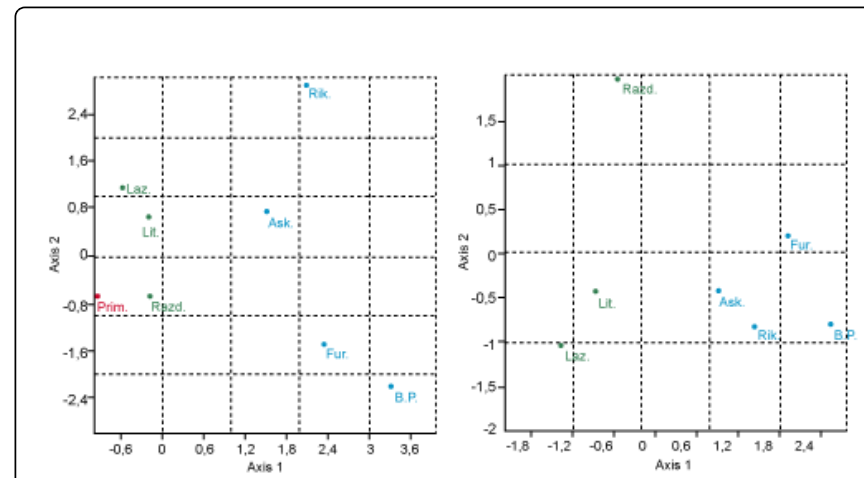

Figure 2: Scatter plot of detrended correspondence analysis for local geometrid faunas in Primorskii region. A - chart with the total species list of Primorskii region included. It is seen that the dots of insular faunas (by sky-blue) are removed far from each other and from the dots of continental local faunas (by green), which are placed close together and to a dot of the total list of geometrids of Primorskii region (by red). This chart demonstrates scantiness and patchiness of insular faunas of geometrids in comparison with continental ones. B - chart with the total species list of Primorskii region excluded. The dots of insular faunas (by sky-blue) are placed close together, showing a negative affinity by lacking species. Legend: Ask. - the Askold Islands, Rick. - the Ricord Islands, B.P. the Bolshoi Pelis Islands, Fur. - the Furugelm Islands, Laz. Lazovsky Nature Reserve, Lit. - Litovka Mountain, Razd. Razdolnaya river, Prim. - Primorskii region.

For the biogeographic analysis, all species of geometrids from primary data matrix were grouped by major types of areas (Table 1) (Figure 3). From them the East Asian species complex (including the East Asian - Indo-Malayan species) dominates in all localities, and varies within a narrow range (in the continental localities within the range $-3.2 \%-+5.0 \%$ and on the islands $--5.3 \%-+3.7 \%$ ) around the specific gravity of this arealogical complex in the total list of geometrids of Primorskii region (58.0\%) (Figure 3).

Arealogical group of widespread species possesses second specific gravity, taking from $28.9 \%$ (in the total list of geometrids of Primorskii region and on the Furugelm Island) up to $34.5 \%$ in the continental local faunas, also with a small scatter of values. However, unlike the East Asian species complex, the deviation from the share of that species in the total list of geometrids of Primorskii region occurs only in the direction of greater specific gravity: in the continental localities from $+1.0 \%$ up to $+4.9 \%$ and on the islands from $0 \%$ up to $+5.6 \%$.

The share of Central Palaearctic - Far Eastern species complex in Primorskii region is not great $-12.3 \%$. Scatter of proportions of this group on the islands is comparatively more significant - ranges from $5.1 \%$ up to $10.6 \%$ and always lower of their total share in Primorskii region. Agrological group of Far Eastern species is so small that not significant to discussion in this work.
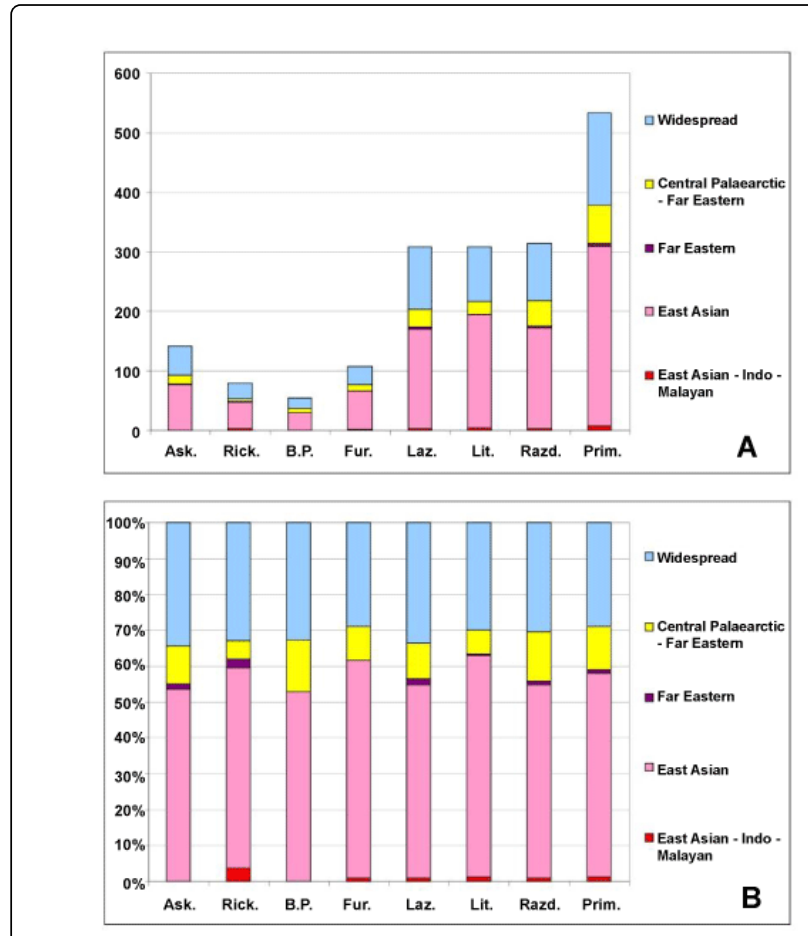

Figure 3: Major arealogical groups of geometrid moths on the islands an in the continental local faunas in Primorskii region. A number of species, B - the share (\%) of species. "Widespread" - the species with broad Palaearctic or Holarctic ranges; "Central Palaearctic - Far Eastern" - the species with ranges covering east of Central Asia, South Siberia, Mongolia, North-East China and countries around the Sea of Japan; "Far Eastern" - the species with ranges covering most northeastern Pacific Asia south to the lands around northern part of the Sea of Japan; "East Asian" - species with ranges covering the extratropical China (except west) and territories neighboring to the Sea of Japan; "East Asian - IndoMalayan" - the species with ranges covering subtropical and tropical zones of East, South and Southeast Asia. The remaining notations see Figure 2.

\section{Discussion}

Fauna of geometrids on the small islands of the Peter the Great Gulf is considerably scantier in comparison with the neighboring continental localities. Even the cumulative species richness of geometrids on all four islands is about one third less than in the each of the local faunas from mainland. Small territories of the islands with comparatively low floristic and habitat diversity could explain this poorness.

Quantitative analysis of the arealogical structure of geometrids on the islands suggests their undoubted biogeographical unity with the neighboring continental localities. Under the proportional composition of the major arealogical groups, the insular faunas of Geometridae are very close to continental localities, also as to total list of geometrids of the Primorskii region. Differences are minor and consist of slightly reduced share of East Asian species, slightly increased proportion of widespread species and somewhat stronger scattered participation of Central Palaearctic - Far Eastern species; the 
latter is not surprising because of narrow and mosaic distribution of most of Central Palaearctic - Far Eastern geometrids in the Far East.

Ponomarenko and Zinchenko [26] obtained similar results, having shown that micromoths on the same islands of the Peter the Great Gulf also possess low species richness, high degree of patchiness of their distribution between them, and high similarity of their arealogical structure with neighboring continental fauna.

Initially these conclusions look as quite expected, given the offshore position of the islands on a small distance from the coast. However, the high similarity of arealogical structure of geometrids and micromoths on the islands with the continental localities is surprising. Taking into account comparatively high scantiness of the insular faunas, isolation of the islands in other climatic epoch and their current original weather conditions, more or less significant difference of arealogical structure of the moths between the islands and continental localities could be expected. Nevertheless, it is not so. What could be the reason for this unexpected result?

According to the classic views of the theory of island biogeography, richness and composition of biota on islands depend on the balance of rate of foreign colonization and rate of extinction of resident populations. On the example of small islands of the Baltic Sea (the Southwestern Archipelago off the coast of Finland) Nieminen and Hanski [27] showed that structure of population and migration of nocturnal Lepidoptera on these islands meet this assumption. Besides, these authors shown the mixed nature of populations of moths on the small islands, included both resident populations and continentalisland metapopulations supported by flow of migrants from the mainland coast.

The studied islands of the Peter the Great Gulf do not fully comply with the conditions on the archipelago explored by Nieminen and Hanski[27]. Although the Finnish islands are placed on similar distance from mainland (in the range of $10-20 \mathrm{~km}$, and the island in the Peter the Great Gulf in the range of 5-14 km), they are included in a vast and dense archipelago, directly bordering the continental coast, which facilitates the migration of insects. In addition, wind and temperature conditions of the Baltic are softer than in the Peter the Great Gulf.

Nevertheless, I assume that conclusions by Nieminen and Hanski are also valid for the islands of the Peter the Great Gulf, provided that the migratory flow between the mainland and the islands could be weaker. The latter should be applied especially to the geometrid moth, because they have moderate migratory abilities. It is shown that, comparing with Noctuidae, they fly at lower altitudes (usually not higher than 10 meters above ground level) [28], and later colonize habitats belonging to early stages of succession [29]. Supposedly, taking into account minute size and weak ability to long purposeful flight, micromoths could possess less migratory abilities than geometrids (especially over the sea), but such investigations are lacking.

Thus, it can be hypothesized that the moths on the small islands the Peter the Great Gulf mainly represented by resident populations, which only occasionally, but regularly over the long time intervals, are replenished by random immigrants from the continental coast. This model could explain both a high degree of patchiness of the species composition of the moths on the islands, as well as a high degree of concordance of their arealogical structure to neighboring mainland, which could be the result of alignment due to randomness of moths migration. Rate of extinction of moths on the islands is difficult to estimate. Apparently, it did not alter the arealogical structure of the moths' fauna on the islands, despite of some peculiarities of their climatic conditions. That is, extinction may be also random.

It should be emphasized that this model can be valid only under important assumption - approximately equal distribution of migratory ability of moths from different arealogical group. However, the question never been examined.

\section{Conclusion}

Equivalence of arealogical structure of geometrid and micromoths inhabited small islands in the Peter the Great Gulf could be explained by alignment of this structure because of random immigration of moths from continental coast of the gulf on the islands under condition of equivalence of migratory ability of moths in the large arealogical group. The proposed hypothesis is preliminary and its verification requires long stationary observations on the moths migratory activity in the archipelago of the Peter the Great Gulf, which was not attempted yet. Therefore, first, the author would like to draw attention to the problem of explanation of equivalence of arealogical structure of lepidopteran assemblages in ecologically similar neighboring localities with strongly different species richness.

\section{Acknowledgements}

The author expresses his sincere gratitude to Dr VV Ivin and Dr IA Kashin (Institute of Marine Biology of RAS, Vladivostok) for the invitation to participate in the study of the fauna of the island of the Peter the Great Gulf, and to management and staff of the Far Eastern State Marine Biosphere Reserve for assistance in the field work. This work was partially supported by RFBR grant No 14-04-00649 and grants of Presidium of Far Eastern Branch of RAS No 12-I-OBN-02, No 12-I-P30-03, No 12-II-0-06-019 and No 12-III-A-06-069.

\section{References}

1. Velizhanin AG (1976) Isolation time of the continental islands in the northern part of the Pacific Ocean. Doklady Akademii Nauk SSSR 231: 205-207.

2. Markov YD (1983) Shelf Zone of the Sea of Japan off the Coast of south Primorye in Late Pleistocene and Holocene. DVNTs AN SSSR, Vladivostok.

3. Beljaev EA (2013) Features of the fauna of geometrid moths (Lepidoptera: Geometridae) on the islands of the Peter the Great Gulf. A.I. Kurentsov's Annual Memorial Meetings 24: 71-100

4. Hedemann W (1881a) Beitrag zur Lepidopteren-Fauna des Amur-Landes (Fortsetznng). Horae Societatis Entomologicae Rossicae 16: 43-57.

5. Hedemann W (1881b) Beitrag zur Lepidopteren-Fauna des AmurLandes (Fortsetznng). Horae Societatis Entomologicae Rossicae 16: 242 $262,257-272$.

6. Hedemann W (1879) Beitrag zur Lepidopteren-Fauna des Amur-Landes. Horae Societatis Entomologicae Rossicae 14: 506-516.

7. Oberthür C (1879) Diagnoses d'espèces nouvelles de Lépidoptères de l'ile Askold. Rennes.

8. Oberthür C (1880) Faune des Lépidoptères de l'ile Askold. Première partie. Etudes d'Entomologie 5: ix-x, 1-88, pls 1-9.

9. Christoph H (1881a) Neue Lepidopteren des Amurgebietes. Bulletin de la Société Impériale des Naturalistes de Moscou 55: 33-121.

10. Christoph H (1881b) Neue Lepidopteren des Amurgebietes. Bulletin de la Société Impériale des Naturalistes de Moscou 56: 1-80, 405-436.

11. Christoph H (1882) Neue Lepidopteren des Amurgebietes. Bulletin de la Société Impériale des Naturalistes de Moscou. 57: 5-47. 
Citation: Beljaev EA (2014) Unexpected Feature of the Lepidoptera Assemblages on the Small Shelf Islands in the Peter the Great Gulf (Sea of Japan, South of Russian Far East). J Biodivers Biopros Dev 1: 113. doi:10.4172/2376-0214.1000113

Page 5 of 5

12. Staudinger O (1892) Die Macrolepidopteren des Amurgebietes. Mémoires sur les Lépidoptères 6: 83-659.

13. Staudinger O (1897) Die Geometriden des Amurgebiets. Deutsche entomologische Zeitschrift Iris 10: 1-122.

14. Novomodnyi EV (2012) Hamburger collector and researcher Fritz Doerris at the Russian Far East. A.I. Kurentsov's Annual Memorial Meetings 23: 18-37.

15. Kurentsov AI (1934) Moths and butterflies on the Furugelm Island. Vestnik DVF AN USSR 10: 122-124.

16. Martinenko AB, Chichvarhin AY (1997) Fauna of butterflies on the islands the Peter the Great Gulf. Zhivotnyy i rastitel'nyy mir Dal'nego Vostoka [Flora and Fauna of the Far East] 3: 5-11.

17. Holloway JD (1986) Origins of Lepidopteran Faunas in high mountains of the Indo-Australian tropics. In: Vuilleumier F, Monasterio M (eds.) High Altitude Tropical Biogeography. Oxford University Press, New York 533-556.

18. Beljaev EA (2006) Geometrids (Lepidoptera, Geometridae) in rare ecosystems of the Western Primorskii Krai: biodiversity, chorology and ecology. A.I. Kurentsov's Annual Memorial Meetings 17: 29-56.

19. Beljaev EA (2009) Family Geometridae. In: Storozhenko SY (ed.). Nasekomye Lazovskogo zapovednika [Insects of Lazovsky Nature Reserve]. Dal'nauka, Vladivostok, p. 258-271 .

20. Mironov VG., Beljaev EA, Vasilenko SV (2008) Fem. Geometridae. In: Sinev SY (ed.). Catalogue of the Lepidoptera of Russia. St. KMK Scientific Press, Petersburg, Moscow, p. 190-227.
21. Hill MO, Gauch HG (1980) Detrended Correspondence Analysis: An Improved Ordination Technique. Vegetatio 42: 47-58.

22. Hammer $\varnothing$, Harper DAT, Ryan PD (2006) PAST - PAlaeontological STatistics. Mer. 1.57. November 23.

23. Gorodkov KB (1986a) Three-dimensional climatic model of potential range and some of its characteristics II. Entomological Review 65: 1-18.

24. Gorodkov KB (1986b) Three-dimensional climatic model of potential range and some of its characteristics I. Entomological Review 65: 19-35.

25. Beljaev EA (2011) Fauna and chorology of geometrid moths (Lepidoptera, Geometridae) of the Russian Far East. Lelei A (ed.). Key to the insects of Russian Far East. Additional volume. Analysis of fauna and general reference titles. Dal'nauka, Vladivostok, p. 158-183.

26. Ponomarenko MG Zinchenko YN (2013) Microlepidoptera of the islands of the Peter the Great Gulf (Lepidoptera): tentative faunistic analysis. A.I. Kurentsov's Annual Memorial Meetings 24: 239-246.

27. Nieminen M, Hanski I (1998) Metapopulations of moths on islands: a test of two contrasting models. Jouirnal of Animal Ecology 67: 149-160.

28. Taylor LR, French RA (1974) Effects of light trap design and illumination on samples of moths in an English woodland. Bulletin of Entomological Research 63: 583- 594 .

29. Woiwod IP, Stewart AJA (1990) Butterflies and moths migration in the agricultural environment. In: Bunce RGH, Howard DC (eds). Species Dispersal in Agricultural Habitats. Bellhaven Press, London, 189-202. 